\title{
SARS-CoV-2: One Year in the Pandemic. What Have We Learned, the New Vaccine Era and the Threat of SARS-CoV-2 Variants
}

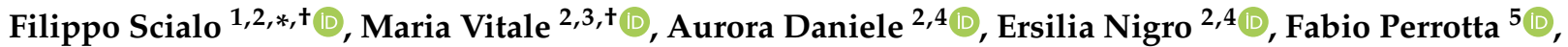 \\ Monica Gelzo 2,3 ${ }^{\text {D }}$, Carlo Iadevaia ${ }^{6}$, Francesco Saverio Cerqua ${ }^{6}$, Adriano Costigliola ${ }^{6}$, Valentino Allocca ${ }^{6}$, \\ Felice Amato $^{2,3}\left(\mathbb{D}\right.$, Lucio Pastore ${ }^{2,3, * \mathbb{D}}$, Giuseppe Castaldo ${ }^{2,3}$ and Andrea Bianco ${ }^{1,6}{ }^{(D)}$
}

1 Dipartimento di Scienze Mediche Traslazionali, University of Campania "L. Vanvitelli", 80131 Naples, Italy; andrea.bianco@unicampania.it

2 CEINGE, Biotecnologie Avanzate, 80131 Naples, Italy; vitalema@ceinge.unina.it (M.V.); aurora.daniele@unicampania.it (A.D.); nigro@ceinge.unina.it (E.N.); monica.gelzo@unina.it (M.G.); felice.amato@unina.it (F.A.); giuseppe.castaldo@unina.it (G.C.)

3 Dipartimento di Medicina Molecolare e Biotecnologie Mediche, Università di Napoli Federico II, 80131 Naples, Italy

4 Dipartimento di Scienze e Tecnologie Ambientali Biologiche Farmaceutiche, University of Campania “L. Vanvitelli", 80131 Naples, Italy

5 U.O.C Pneumologia Azienda Ospedaliera Sant'Anna e San Sebastiano, 81100 Caserta, Italy; dott.fabioperrotta@gmail.com

check for updates

Citation: Scialo, F.; Vitale, M.; Daniele, A.; Nigro, E.; Perrotta, F.; Gelzo, M.; Iadevaia, C.; Cerqua, F.S.; Costigliola, A.; Allocca, V.; et al. SARS-CoV-2: One Year in the Pandemic. What Have We Learned, the New Vaccine Era and the Threat of SARS-CoV-2 Variants. Biomedicines 2021, 9, 611. https://doi.org/ $10.3390 /$ biomedicines 9060611

Academic Editor: Shaker A. Mousa

Received: 13 April 2021

Accepted: 20 May 2021

Published: 27 May 2021

Publisher's Note: MDPI stays neutral with regard to jurisdictional claims in published maps and institutional affiliations.

Copyright: (c) 2021 by the authors. Licensee MDPI, Basel, Switzerland. This article is an open access article distributed under the terms and conditions of the Creative Commons Attribution (CC BY) license (https:// creativecommons.org/licenses/by/ $4.0 /)$.
6 Pneumology Vanvitelly-COVID Unit A.O. dei Colli Hospital Monaldi, 80131 Naples, Italy; dott.carlo.iadevaia@gmail.com (C.I.); fscerqua@gmail.com (F.S.C.); neon17ster@gmail.com (A.C.); valentino.allocca@unicampania.it (V.A.)

* Correspondence: filippo.scialo@unicampania.it (F.S.) ; lucio.pastore@unina.it (L.P.)

+ These authors contributed equally to this work.

\begin{abstract}
Since the beginning of 2020, the new pandemic caused by SARS-CoV-2 and named coronavirus disease 19 (COVID 19) has changed our socio-economic life. In just a few months, SARS-CoV-2 was able to spread worldwide at an unprecedented speed, causing hundreds of thousands of deaths, especially among the weakest part of the population. Indeed, especially at the beginning of this pandemic, many reports highlighted how people, suffering from other pathologies, such as hypertension, cardiovascular diseases, and diabetes, are more at risk of severe outcomes if infected. Although this pandemic has put the entire academic world to the test, it has also been a year of intense research and many important contributions have advanced our understanding of SARS-CoV-2 origin, its molecular structure and its mechanism of infection. Unfortunately, despite this great effort, we are still a long way from fully understanding how SARS-CoV-2 dysregulates organismal physiology and whether the current vaccines will be able to protect us from possible future pandemics. Here, we discuss the knowledge we have gained during this year and which questions future research should address.
\end{abstract}

Keywords: COVID19; SARS-CoV-2; coronavirus; ACE2; renin angiotensin aldosterone system; kinin-kallikrein system

\section{Introduction}

The last two decades have been punctuated by the sudden appearance of viruses able to quickly spread among continents and cause large-scale pandemics, such as SARS-CoV in 2003, MERS-COV in 2012, and SARS-CoV-2 since the beginning of 2020 [1]. At present, one year from the start of the COVID-19 pandemic, the efforts of the academic world and pharmaceutical industry have resulted in the development of better therapies and the production of multiple vaccines that hold promise for a better future. Unfortunately, despite this great effort, we are still far from fully understanding the mechanisms that 
SARS-CoV-2 uses to dysregulate many physiological pathways causing hyperactivation of the immune response and multiorgan dysfunction [2]. In fact, COVID-19 is not only a lung disease, and unravelling the molecular pathways dysregulated by SARS-CoV-2 in different organs will help to develop specific therapies [3]. Moreover, the appearance of new SARS-CoV-2 variants is constantly raising the question of whether the currently available vaccines have the potential to prevent possible future pandemics. Here, we first discuss what we have learned about SARS-CoV-2's origin, mechanism of infection, and how its sequence has changed, collecting the available information about the impact of SARS-CoV-2 new variants. We will then focus on the main role that the dysregulation of its receptor ACE2 plays in determining disease progression, especially in the organs that seem to be more affected. We will discuss how the dysregulation of the Renin-angiotensin aldosterone system (RAAS) and Kinin-Kallikrein system (KKS) [4] can, in part, explain the overproduction of proinflammatory cytokines and the coagulopathy seen in severe cases of COVID-19. Furthermore, we will describe the available therapies offered at present, and how the advancement in our understanding of SARS-CoV-2 infection is leading to the development of new treatments. Finally, we will discuss how the current vaccination campaign taking place worldwide is affecting the rate of infection and death, especially among the weakest part of the population.

\section{SARS-CoV-2 Origin and Molecular Structure}

Coronaviruses $(\mathrm{CoV})$ are enveloped positive-stranded RNA viruses belonging to the Coronaviridae family. Four members of this family-CoV-NL63,-229E, -OC43, and -HKU1 - have already been identified in humans and known to cause endemic mild respiratory tract infection, although fatal outcomes have been reported, particularly in immunocompromised patients [5]. In the last twenty years, three newly identified members of this family have been responsible for causing epidemic severe acute respiratory syndrome (SARS) , from which they have been named SARS-CoV, middle east respiratory syndrome (MERS), and SARS-CoV-2 [6,7], the latter of which is responsible for the ongoing outbreak. Several studies have demonstrated that the natural reservoir host for these viruses is bats [8]; usually, infection of an intermediate species occurs prior to transmission to humans (Figure 1).

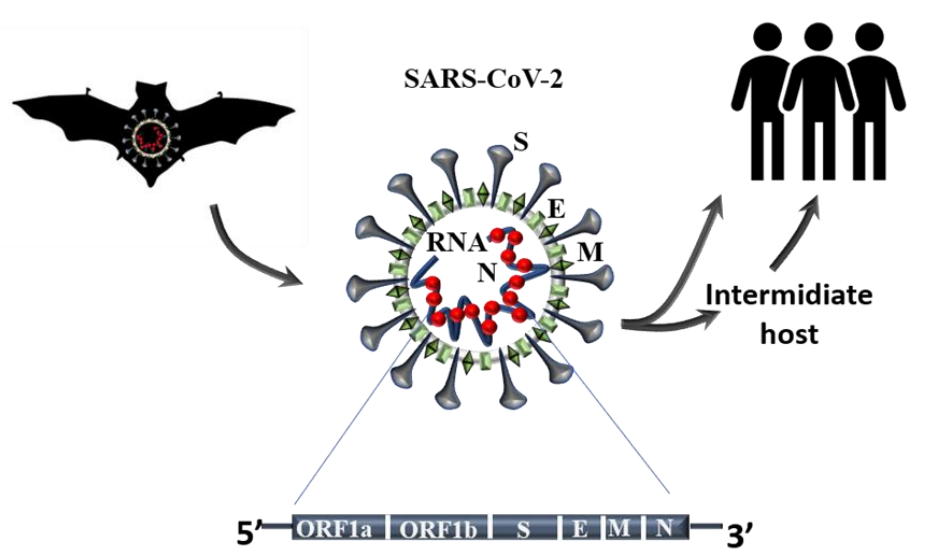

Figure 1. SARS-CoV-2 origin and molecular structure. The natural reservoir of the new betacoronavirus Sars-CoV-2 has been demonstrated to be bats and thought to spread to humans through an intermediate host. The viral RNA is associated with the N proteins that are involved in the key process of infection such as transcription, replication, and packaging. The lipid membrane that protects the viral RNA contains structural proteins such as membrane (M) and envelope proteins (E). The spike glycoprotein (S) , through its receptor-binding domain, is responsible for the recognition of the host cell receptor. The picture shows a simplification of the viral genome.

To date, all evidence suggests that SARS-CoV-2 is the result of an infection from an intermediate host and not a result of laboratory manipulation [8]. In fact, since the 
first outbreak in 2002, a considerable number of SARS-like viruses have been identified in bats and shown to have the capacity to infect humans [7], supporting the hypothesis that potential future outbreaks are possible. The diversity in the coronavirus family is generally believed to be due to the lack of proofreading activity of the RNA-dependent RNA polymerase (RdRp) which is necessary for viral RNA replication. Recent data have instead shown that RdRp of both SARS-CoV and SARS-CoV-2 has proofreading activities and a decrease in the replication fidelity is probably due to mutations in a specific exon [9]. Indeed, although SARS-CoV-2 is closely related to SARS-CoV, sharing $96 \%$ of its identity (Table 1), genomic analysis has demonstrated that mutations in the spike glycoprotein of SARS-CoV-2 increased the affinity for its receptor ACE2 [8].

Table 1. Percentage of RdRp identity related to SARS-CoV-2 and different family of Coronavirus. Sequence reference are respectively YP_009725307, QHR63299.1, QDF43819.1, NP_828869.1, YP_009047223.1, AIW52769.1, YP_459941.1, AIW52828.1, YP_009555260.1.

\begin{tabular}{ccccccccc}
\hline \multirow{2}{*}{ SARS-CoV-2 } & \multirow{2}{*}{ Bat CoV } & $\begin{array}{c}\text { BtRs- } \\
\text { BetaCoV/YN2018A }\end{array}$ & SARS -CoV & MERS & $\begin{array}{c}\text { hCoV } \\
\text { 229E }\end{array}$ & $\begin{array}{c}\text { hCoV } \\
\text { HKU1 }\end{array}$ & $\begin{array}{c}\text { hCoV } \\
\text { NL63 }\end{array}$ & $\begin{array}{c}\text { hCoV } \\
\text { OC43 }\end{array}$ \\
\hline & $99 \%$ & $96 \%$ & $96 \%$ & $70 \%$ & $58 \%$ & $67 \%$ & $59 \%$ & $66 \%$ \\
\hline
\end{tabular}

\section{The Effect of Sars-Cov-2 New Variants}

Structurally, the spike glycoprotein is formed by two subunits, named S1 and S2. The $\mathrm{S} 1$ subunit is responsible for receptor binding and can be further divided into $\mathrm{N}$ terminalsubunit (NTD) and the receptor-binding domain (RBD). The S2 subunit is necessary for the membrane fusion between the virus envelop and the late endosome membrane. Moreover, the genomic structure of the viral RNA, 2.9kb in length [10], contains genes necessary for its replication, such as the RdRp and helicase (HEL), genes encoding structural proteins such as membrane $(\mathrm{M})$, nucleocapsid $(\mathrm{N})$ and envelope protein $(\mathrm{E})$ and, as we discussed above, the spike glycoprotein $(S)$, responsible for host recognition [8].

In the months of 2020, more attention was focused on the identification of new SARSCoV-2 variants, some of which have caused an unexpected increase in COVID-19 cases. For instance, the variant 501Y.V1 (B.1.1.7) , known also as the English variant, has been associated with an increased infectivity and high transmission through populations, possibly due to an enhanced affinity for its receptor ACE2. At the same time, in South Africa, another variant called 501Y.V2 (B1.351) is spreading widely through the population [11-13]. These two variants share a mutation in the RBD of the spike protein, with the South African variant having two additional mutations, E484K and $\mathrm{K} 417 \mathrm{~N}$, that allow the immune escape of SARS-CoV-2 and, in particular, to the neutralizing antibodies [12,13]. Another variant identified in Brazil (P.1 (501Y.V3) ) , shows three mutations in the RBD, shared with south African variants, but the infectivity rate of this variant is still under investigation (Figure 2) . At this point, the most relevant issue is whether the available COVID-19 vaccines will be able to protect the population from these and new variants that will be identified. It is worth remembering that the three main vaccines, Pfizer BioNTech, Moderna, and Oxford AstraZeneca, which have already been administered to millions of people, target the spike protein. Some tests are underway to evaluate their effectiveness against these variants, even if the spike protein is a large protein and a lot of mutations would be needed to completely escape the immune system [11]. 


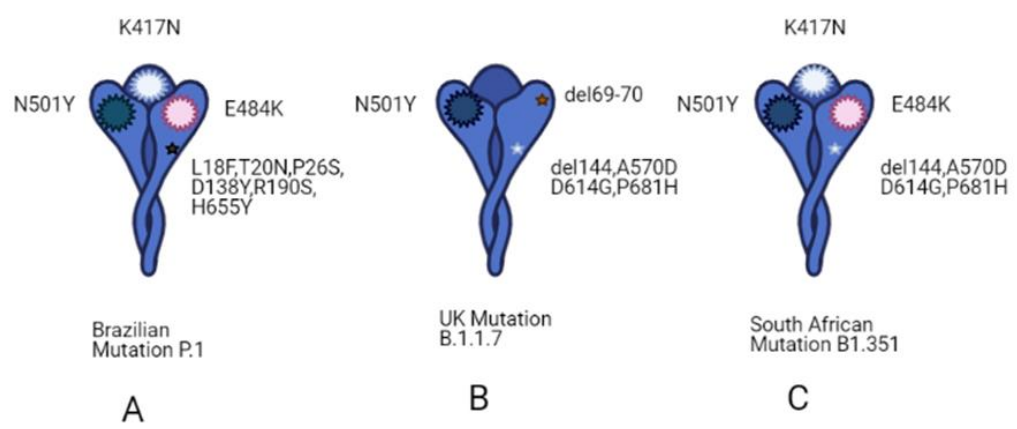

Figure 2. Schematic representation of spike variants. (A) Brazilian mutation called P.1, that shares three mutations in the RBD domain of spike protein with South African variants (N501Y, E484K and K417T) ; P.1 has 17 amino acid changes, nine of which are in its spike protein (L18F, T20N, P26S, D138Y, R190S, H655Y) . (B) English mutation called B1.1.7 has a mutation (N501Y) in the RBD of the spike protein like P.1 and B1.351 variants. Additionally, amino acid deletions were found within the N-terminal domain (NTD) of spike protein, important for efficient entry into host cells. (C) South African mutation called B1. 351, shows a mutation in spike protein (N501Y, E484K and K417T) and several changes in NTD spike domain (A570D, D614G, P681H), including amino acid deletion (del144) . [14] Created with BioRender.com.

\section{SARS-CoV-2 Mechanism of Infection and Immune Response Activation \\ 4.1. Mechanism of Infection}

Experimental evidence has demonstrated that ACE2 is used by SARS-CoV-2 as the main entry point into the cells $[1,14,15]$. As described above, the S1 unit of SARS-CoV-2 $S$ protein is responsible for binding with the host cell receptor ACE2. Here, the $S$ protein can be cleaved by the protease TMPRSS2 [16] between S1/S2 units, allowing for direct fusion with the cellular membrane mediated by the S2 unit (Figure 3). Alternatively, after binding with ACE2, SARS-CoV-2 can take advantage of the endocytic pathway to enter the cells (Figure 3) . Apilimod and YM201636, two potent inhibitors of phosphatidylinositol3,5-bisphosphate (PI $(3,5)$ P2), which controls endosome dynamics, have been shown to greatly reduce SARS-CoV-2 entry. Upon fusion with the lysosome, cathepsin-L will drive the proteolytic cleavage of the Spike glycoprotein activating the S2 subunit and the consequent membrane fusion to release the viral RNA into the cytoplasm [17]. Here, the viral RNA will be translated to form RdRp and Hel, important for its transcription and replication. Structural proteins will be transcribed, translated in the endoplasmic reticulum, and transported to the Golgi. The new viral RNA with the structural proteins will be used to build a new virus in the ER-Golgi intermediate compartment (ERGIC), which is released by exocytosis and ready to infect other cells (Figure 3). Although ACE2 has been demonstrated to be the major receptor for SARS-CoV-2, the intense research into its mechanism of infection coupled with the screening of compounds to reduce its entry into the cells, has led to the identification of other receptors that could possibly play a role in the severity of the disease and explain how this virus is able to target multiple organs. For instance, Meplazumab, an anti-CD147 antibody, has been demonstrated to inhibit SARS-CoV-2 infection in Vero cells [18]. CD147 receptor belongs to the immunoglobulin superfamily and, in contrast to ACE2, is mainly expressed in the brain [19], which could, in part, explain the neurological problems in COVID-19 patients. Neuropilin 1 (NRP1) has also been shown to bind the SARS-CoV-2 Spike protein [20] and, since it is abundantly expressed in the epithelial cells of the olfactory bulb, this could also explain the high rate of infectivity of this virus. 


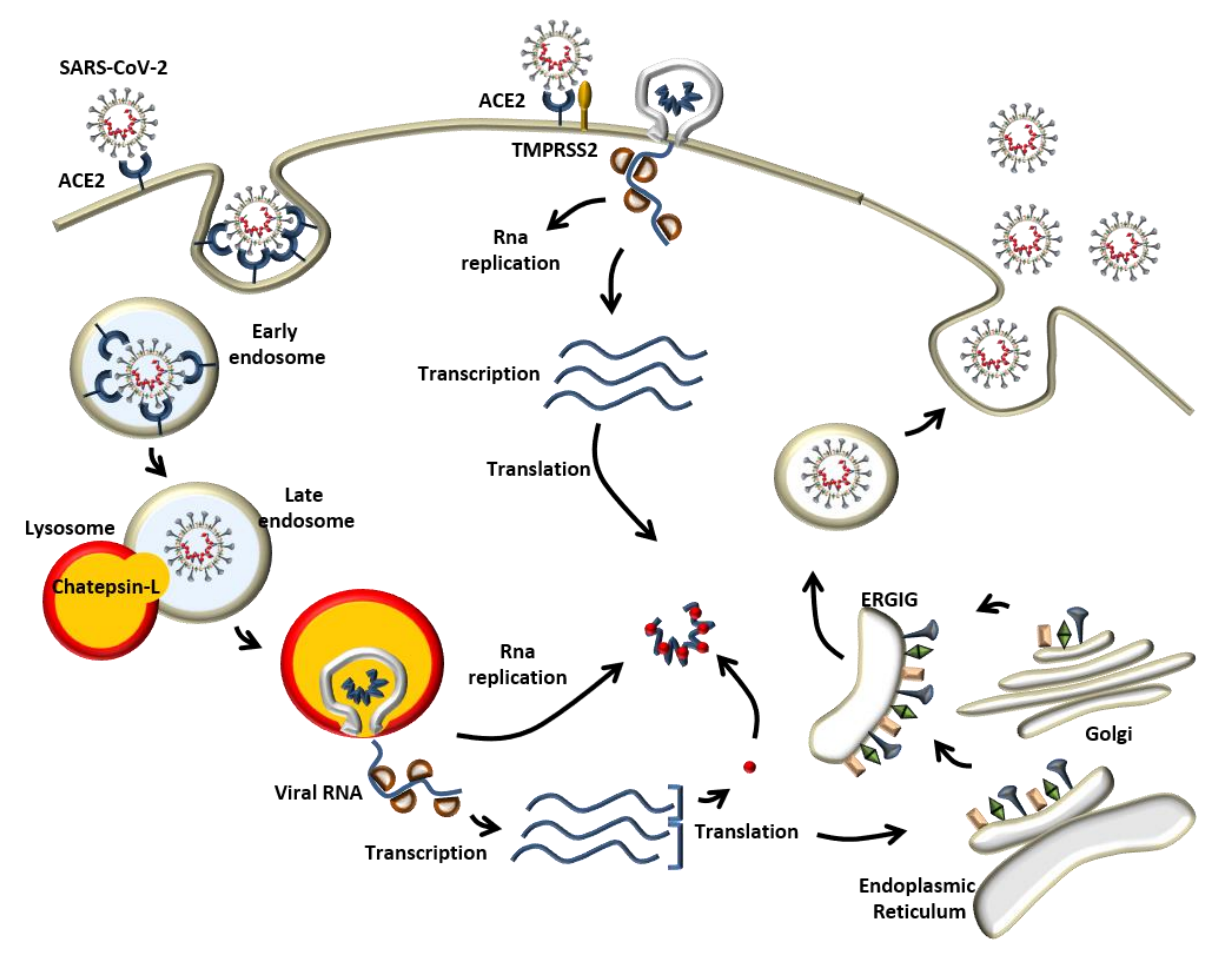

Figure 3. Mechanism of infection. SARS-CoV-2 recognizes the host cell by binding with the Angiotensin- converting enzyme 2 (ACE2) via Spike glycoprotein S1 unit. The priming of the Spike glycoprotein can be mediated by the TMPRSS2 protease that allows virus/membrane fusion guided by the $\mathrm{S} 2$ unit. Alternatively, the virus can enter the cell by using the endocytic pathway where Chatepsin-L cleaves the S protein allowing also in this case the priming of the late endosome membrane with the S2 unit. The viral RNA will undergo transcription and replication. The new viral particle will be built in the ER-Golgi intermediate compartment (ERGIC) and released by exocytosis.

\subsection{Immune Response Activation}

Laboratory abnormalities of most affected COVID-19 patients include neutrophilia, lymphopenia, increased $\mathrm{C}$ - reactive protein, and pro-inflammatory cytokines such as interleukin 6 (IL-6) , IL-2, IL-7 and tumor necrosis factor-alpha (TNF $\alpha$ ) among others [21]. The activation of the immune response starts with the recognition of virus components generally called pathogen-associated molecular patterns (PAMPs), such as single-strand RNA (ssRNA) or double-strand RNA (dsRNA), formed as an intermediate during RNA replication. ssRNA and dsRNA can be identified by the cellular pattern recognition receptors (PRRs) such as the Toll-Like (TLR) and RIG-I/MDA5 pathway, respectively (Figure 4). The latest scientific findings have demonstrated that MDA5 is the major sensor involved in the recognition of SARS-CoV-2. The infection of different model systems such as lung epithelial cells CALU-3, intestinal cells CACO-2 and nasal epithelial-derived cells has been shown to induce a strong expression of MDA5 upon SARS-CoV-2 infection, together with other viral RNA sensors such as LGP2 and NOD1 [22-24]. The activation of the endosomal TLR3/7 and RIG-I/MDA5 pathway will then initiate a signalling cascade that results in the translocation of the NF-kb and Interferone Regulatory 3/7 transcription factor (IRF3/7) into the nucleus and the transcription of pro-inflammatory cytokines and chemokines such as TNF $\alpha$, IL-6 and Interferon 1 (IFN1). IFN1 is then transported out of the cells to bind the IFNAR receptor and guide the transcription of more IFN1 and IFNstimulated genes that, in combination with the cytokine gradient, are necessary to recruit neutrophils, macrophages, and other immune cells to the site of infection (Figure 4). One of the problems is that SARS-CoV-2 might have the ability to inhibit IFN1 production [25]. In fact, in the same model system described previously, it has also been shown that SARSCoV-2 infection induced a delayed interferon response compared with other viruses $[22,23]$. 
Two interesting works have demonstrated that SARS-CoV-2 can operate this inhibition through different molecular mechanisms. One is represented by the papain-like protease activity of the gene NSP3 that has been demonstrated to inhibit the ISGylation of MDA5, which is important for its activation, delaying, in this way, the Interferon Stimulated Gene (ISG) response [26]. The second mechanism relies on the ability to inhibit the IRF3/7 nuclear translocation operated by the SARS-CoV-2 NSP12 gene that encodes the RdRp [27].

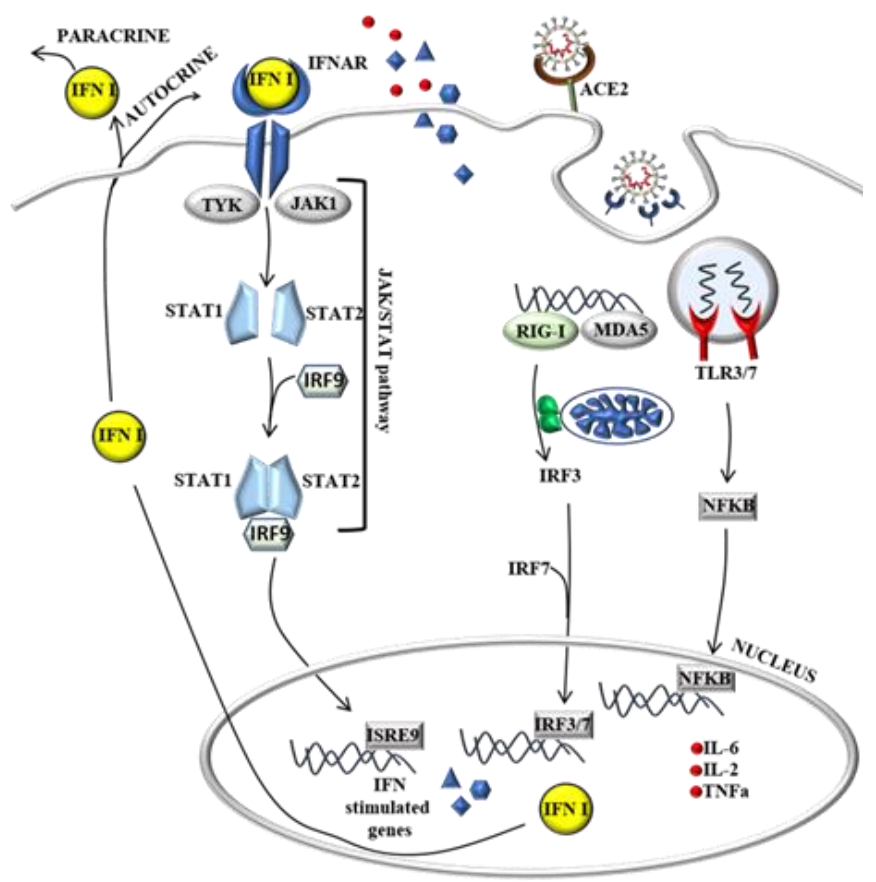

Figure 4. Immune response activation due to SARS-CoV-2 infection. The presence of virus particles in the cell, such as the viral RNA, is recognized by the Toll-Like and RIG-I/MAD5 pathway and will initiate signaling cascades resulting in the translocation of NF-kb and IRF3/7 into the nucleus and the transcription of pro-inflammatory cytokines that are responsible for recruiting immune cells to the site of infection (left) .

\section{Dysregulation of RAAS and KKS as a Probable Cause of the Immune Response Overactivation}

Although the activation of the immune response is crucial to fight the infection, the overproduction of pro-inflammatory cytokines, also known as a "cytokine storm", can lead to apoptosis and tissue damage, characteristics seen in patients critically ill with COVID19 [28]. In fact, different works have demonstrated that the level of specific cytokines and chemokines is related to disease severity and these could be used as parameters to follow disease progression. For instance, Liang et al. demonstrated that, while IL- 8 is constantly elevated in COVID-19 patients, IL-6 and IL-10 increase was correlated with the severity of the infection. The same was true for the chemokine Interferon-y protein 10 (IP-10) which is only transiently increased in the common influenza, while in COVID19 patients its expression remains constant and, as with IL-6 and IL-10, is correlated with disease severity [29]. A mechanism that could explain an overproduction of proinflammatory cytokines or worsening of the infection is the dysregulation of the RAAS caused by SARS-CoV-2-dependent ACE2 internalization. Indeed, the accumulation of AngII due to a decreased ACE2 membrane level can cause vasoconstriction, the production of pro-inflammatory cytokines, and reactive oxygen species (ROS) generation through the overactivation of its receptor AT1R. In a recent work, it has been demonstrated that the infusion of AngII or an ACE2 blocker in swine can recapitulate several symptoms seen in COVID-19 patients, such as alveolar damage and increased coagulation [30]. It is important to note that ACE2 also plays an important role in the regulation of the KKS system. Indeed, 
it can inactivate [des-Arg9]-BK (DABK) and Lys-[des-Arg9]-BK (LDABK) that, through the BRB1 receptor, promotes pro-inflammatory cytokines production and angioedema [4] (Figure 5) . It has been shown that levels of components of the complement pathways and the KKS were strongly correlated with severity and death in COVID19 patients [31] and some first evidence is indicating that KKS inhibitors could be beneficial in improving lung function in COVID19 patients [32].

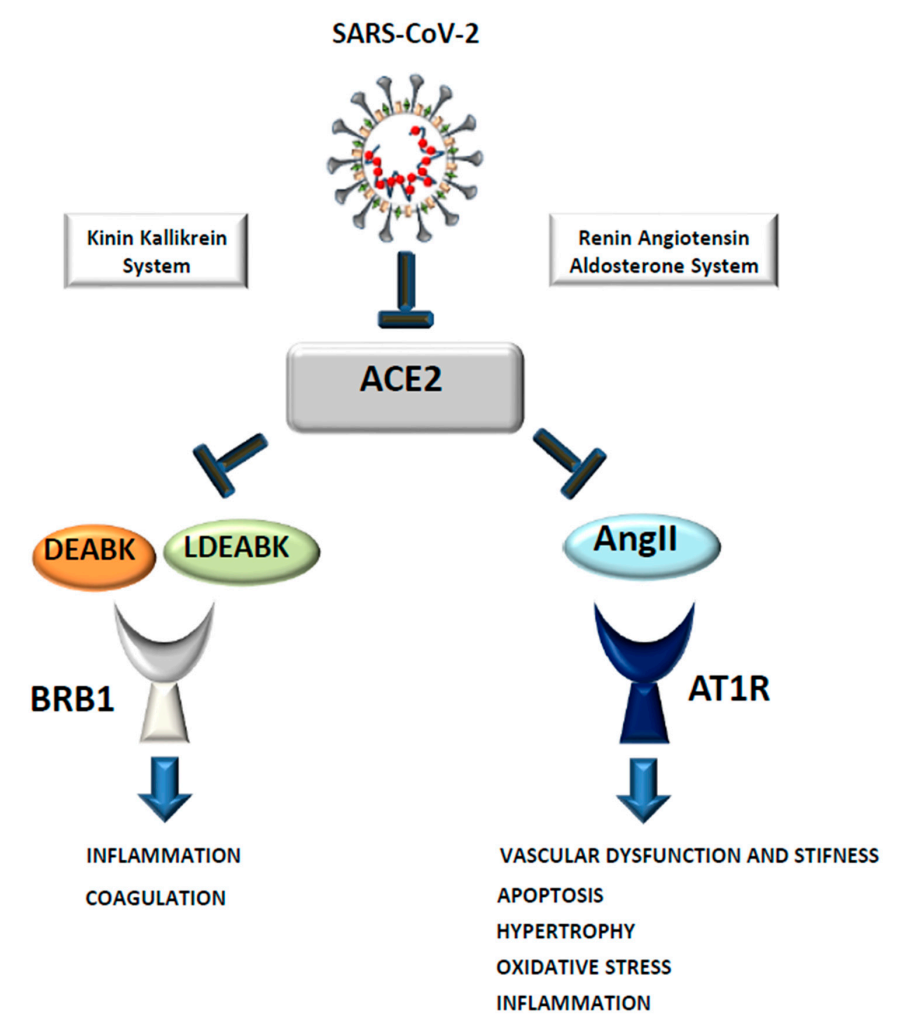

Figure 5. SARS-CoV-2 dependent ACE2 internalization as a possible cause of the cytokine storm. The binding of SARS-CoV-2 to ACE2 can cause its internalization and a decreased level on the plasma membrane. This leads to an increase in AngII and DEABK/LDEABK causing vasoconstriction, apoptosis, oxidative stress, and an overproduction of proinflammatory cytokines through their receptor AT1R and BRB1.

Furthermore, it appears that ACE2 localization has a key role in determining disease severity. Critically ill COVID-19 patients show a pulmonary hypercoagulable state $[4,28,33,34]$ and it has been suggested that the proximity of type II alveolar epithelial cells expressing ACE2 to the pulmonary microvasculature could be the reason for the diffuse thrombotic events caused by the hyper inflammation. The early assessment of biomarkers such as D-dimer, creatine kinase, and troponin T could help in the prediction and prevention of possible development of pulmonary intravascular coagulopathy [15].

\section{Potential Treatments for COVID19: The Need to Find Multiple Therapeutic Options}

The clinical reports published since the first outbreaks in December 2020 have indicated which part of the population is more at risk. In Table 2 we have summarized the findings of several studies, where advancing age [35], male sex, and the presence of comorbidities such as hypertension, diabetes, and cardiovascular disease seem to represent the main risk factors for severe outcomes [36]. Recently, obesity has been indicated as an additional risk factor, which can promote severe outcome in subjects infected with SARS-CoV-2. Kompaniyets and colleagues have reported a relationship between body mass index (BMI) and severe infection, probably due to the high level of inflammation characteristic of obese people [37]. 
Table 2. Percentage of COVID19 patients with pre-existing conditions identified in the reported clinical studies.

\begin{tabular}{|c|c|c|c|c|c|c|c|}
\hline Clinical Report & Nr Cases & Age & Males & Females & CVD & Diabetes & Hypertension \\
\hline Zhonghua Liu Xing 2020 [38] & 44672 & $30-69(77.8 \%)$ & $51.4 \%$ & $48.6 \%$ & $4.2 \%$ & $1.1 \%$ & $12.8 \%$ \\
\hline Xie J et al., 2020 [39] & 168 & $>50$ & $75 \%$ & $25 \%$ & $18.5 \%$ & $25 \%$ & $50 \%$ \\
\hline Guan WJ et al., 2020 [21] & 1099 & $>50(56 \%)$ & $58.1 \%$ & $41.9 \%$ & $2.5 \%$ & $7.4 \%$ & $15 \%$ \\
\hline Huang C et al., 2020 [40] & 41 & 49 median & $73 \%$ & $27 \%$ & $15 \%$ & $20 \%$ & $15 \%$ \\
\hline Zhang JJ et al., 2020 [41] & 140 & 57 median & $50.7 \%$ & $49.3 \%$ & not specified & $12.1 \%$ & $30 \%$ \\
\hline Li Q et al., 2020 [42] & 425 & 59 median & $56 \%$ & $44 \%$ & & not specified & \\
\hline Wang D et al., 2020 [43] & 138 & 56 median & $54.3 \%$ & $45.7 \%$ & $10.1 \%$ & $14.5 \%$ & $31.2 \%$ \\
\hline Chen N et al., 2020 [44] & 99 & 55.5 median & $67.7 \%$ & $32.3 \%$ & $40 \%$ & $13 \%$ & $3 \%$ \\
\hline Shi H et al., 2020 [45] & 81 & 49.5 median & $52 \%$ & $48 \%$ & $10 \%$ & $12 \%$ & $15 \%$ \\
\hline Liang WH 2020 [46] & 1590 & 48.9 median & $57.3 \%$ & $42.7 \%$ & $3.7 \%$ & $8.2 \%$ & $16.9 \%$ \\
\hline
\end{tabular}

In fact, after one year in this pandemic, although COVID19 has been shown to spread among young and middle-aged people, where only a small percentage develop severe symptoms $[47,48]$, indicating that our efforts should be concentrated towards finding better therapies in subjects that are often treated for other pathologies. It is crucial to understand to what extent underlying diseases and their treatment could represent a risk factor for severe outcomes. Another important aspect to note is the risk of concomitant bacterial infection, which has previously been shown to exacerbate the symptoms of influenza viruses [49].

Today, there are no specific treatments for COVID-19 and all strategies being applied are entirely supportive [3], with many clinical trials underway that have not yet offered definitive support to any particular treatment. Since the beginning of this pandemic, different classes of drugs or treatments have been tested against SARS-CoV-2 infection, including anti-viral (AV) drugs, anti-inflammatory (AI) , monoclonal antibody (MA), plasma therapy (PT) and cell-based therapy (CT) .

At the time of writing, the website clinicaltrial.gov reports more than five thousand clinical trials underway worldwide (Figure 6), of which 980 have been completed.

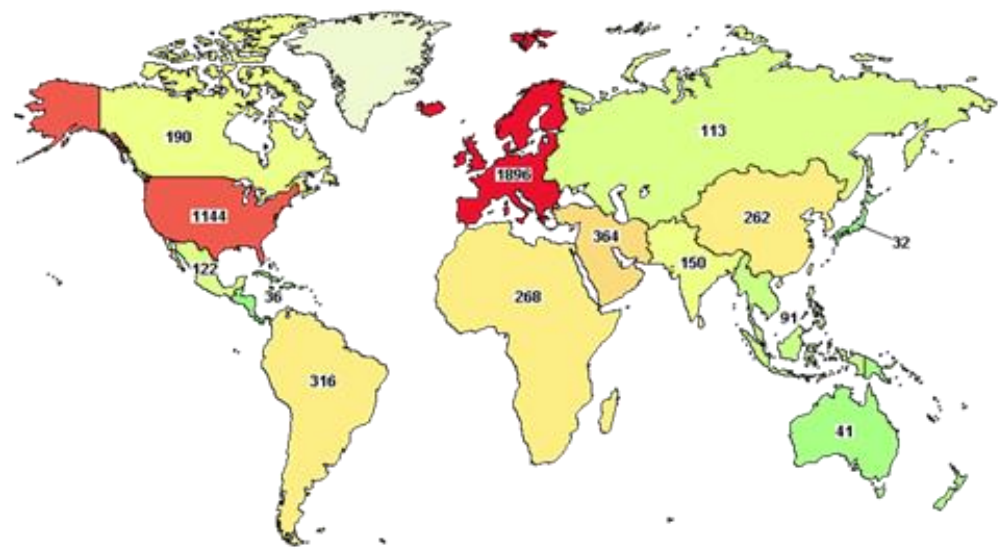

Figure 6. Map of COVID19 clinical trials. This map has been obtained by using clinicaltrial.gov searching for COVID-19 clinical trials for the age 65 and above.

An advanced search shows that half of these trials (2554) are focused on subjects older than 65 years, as discussed above, demonstrating the urgency of finding better therapies for the strata of the population that has suffered more from the effects of this pandemic. Among these trials, only 17 have been completed and they include the use of Ivermectin (AV) , alone or in combination with Doxycycline, Hydroxychloroquine monotherapy (AV) and in combination with Azithromycin (AI) , Favipavir (AV) , Remdesivir (AV) , Convalescent Plasma. Ivermectin is an FDA-approved AV drug, known since 1981 and proven to work against different RNA viruses, such as Avian influenza A, Zika, yellow fever, dengue, among others, and recently shown to completely block SARS-CoV-2 replication in vitro. 
This drug is normally well tolerated, with minimal side effects and, hopefully, when published, the results of these clinical trials will advise its use in COVID-19 subjects [50]. Other AV drugs, Chloroquine and Hydroxychloroquine, have been shown to inhibit viral entry, but the clinical reports published are vague and often present many limitations, such as an inadequate number of patients and no medical or safety outcome being described [51,52]. It is also worth remembering that both drugs have been shown to cause severe side effects, such as cardiotoxicity and hypoglycemia [53,54] that, as described previously, could cause harm in particular subjects with cardiovascular disease or diabetes who are more at risk of developing severe COVID-19 infection. Furthermore, more precautions should be used in subjects with Glucose-6-phosphate dehydrogenase deficiency [55]. Remdesivir (AV) , proposed as a treatment for Ebola, blocks viral RNA replication through the inhibition of RdRp and has been demonstrated to control SARS-CoV-2 infection in vitro and in vivo [56]. The final report published on 1062 patients demonstrated that Remdesivir improved recovery in adults with COVID-19 and the decrease in mortality rate was statistically significant [57]. Like Remdesivir, Favipavir (AV) is an antiviral drug, able to inhibit the RdRp and, although the data of the current clinical trial have not been published yet, early indications have demonstrated a decreased viral load in COVID-19 patients [58]. Different studies have shown that plasma from convalescent patients $(\mathrm{CP})$ can also improve the clinical outcome in severely ill patients [59], although this may not be the best therapeutic strategy when an extremely high number of patients needs to be treated. Beyond the molecules just described, many other repurposed FDA-approved drugs have been used to treat SARS-CoV-2 infections. For the sake of space, and because the description of the molecular mechanisms specific to each drug is beyond the scope of this review, we have listed them in Table 3 and refer the readers to other works, where their mode of action is described in detail [60].

Table 3. Principal class of repurposed drugs involved into treatment of SARS-CoV-2.

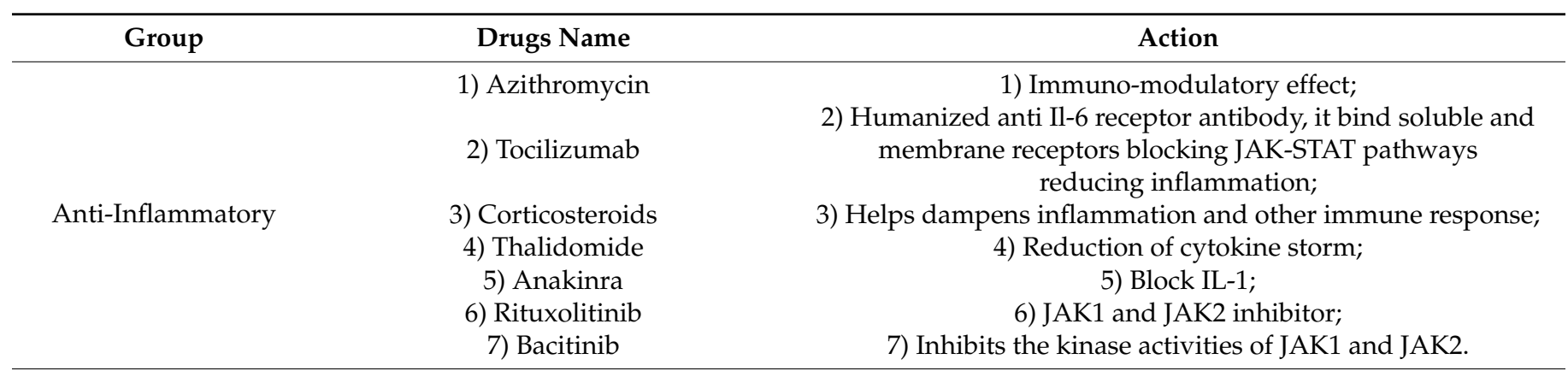

1) Hydroxychloroquine;

2) Camostat;

3) Remdesivir;

Anti-Viral
4) Lopinavir;
5) Ritonavir;
6) Favipiravir;
7) Umifenovir;
8) Ivermectin.

1) Casirivimab;

2) Imdevimab;

3) Bamlanivimab.

1) Inhibit the virus entry into host cells increasing endosomal $\mathrm{pH}$ resulting in inhibition of membrane fusion between host cell and virus;

2) Block viral maturation and entry into host cells;

3) It terminates RNA synthesis and inhibits SARS-CoV-2 genome replication;

4) Protease inhibitor, used in combination with ritonavir improving anti-viral activity;

5) Used in combination with lopinavir;

6) It is a guanine analogue, inhibits RNA polymerase; 7) Inhibit viral and cellular membrane fusion; 8) Block viral replication.

Monoclonal Antibody

serum (convalescent plasma)

1) Block viral entry into host cell;

2) Block viral entry into host cell;

3) Block viral entry into host cell.

\begin{tabular}{ccc} 
Plasma Therapy & Immune serum (convalescent plasma) & Exploitation of virus-specific antibod \\
\cline { 2 - 3 } Cell- Based Therapy & 1) Mesenchymal stem cell; & 1) Ameliorate tissue regeneration;
\end{tabular}

The abbreviations are as follow: Janus kinase/signal transducers and activators of transcription (JAK-STAT) , Interleukin 1 (IL-1) , Janus Kinase 1 (JAK1), Janus kinase 2 (JAK2) . 


\section{A Race for a COVID19 Vaccine}

Although some of these treatments are giving promising results, we are still far from having a standardized therapy protocol and, in many cases, the specific treatment and time of administration are crucial and can change among patients based on their health, age, and coexisting conditions. It is evident that a long-term strategy to fight SARS-CoV-2 infection is to reach herd immunity, with the administration of a specific vaccine to the entire world population. Since the publication of SARS-CoV-2 genetic sequences, the race for the development of a vaccine has interested both the private and public sectors. Multiple approaches have been applied, including the use of nonreplicating viral vectors, messenger RNA (mRNA), inactivated whole-virus and DNAbased vaccines, all having the spike protein as a target [61]. These efforts have resulted in the development and production of different vaccines, some of which, such as Pfizer (BTN162b2) with an efficacy of 95\% in preventing Covid-19 infection [62], Moderna with 90\% mRNA 1273 and AstraZeneca with 70\%, already being used to vaccinate millions of people. BTN162b2 and mRNA 1273 are mRNA-based SARS-CoV-2 vaccines, designed with an open reading frame of the spike protein with a polyadenylation signal at $3^{\prime}$ end, that stimulate humoral and cellular immune responses $[63,64]$. The mRNA is protected from degradation with warp in lipid nanoparticle. This lipid nanoparticle is not only a vehicle for the mRNA but is an adjuvant, increasing the $\mathrm{T}$ follicular helper and $\mathrm{B}$ cell of germinal centre response $[64,65]$. While this kind of vaccine can induce mild side effects, such as fatigue, headache, localized pain at the injection site and myalgia, the antibody response is high and long term, especially after the booster dose [66-68]. Another vaccination method is based on non-replicating adenoviral vectors. Adenoviruses (Ads) are an ideal vector candidate for SARS-CoV-2 vaccines due to their capacity to infect target cells and express transgene at a high level [69]. Furthermore, the Ads-mediated infection can induce the upregulation of costimulatory molecules that stimulate the cytokine and chemokine responses with a consequent improvement of the immune response [70]. The major disadvantage of Ads based vaccines is the pre-existing immunity against different Ads strains; in fact, Ads are common pathogens that cause a mild respiratory infection. Oxford University, in collaboration with AstraZeneca, has designed a chimpanzee adenovirus vector vaccine that expresses a whole spike protein, overriding the problem related to pre-existing immunity [71]. Generally, all vaccines based on non-replicating vectors are safe and immunogenic, inducing the production of anti-spike protein antibodies with mild side effects. Additionally, Janssen Pharmaceutical Companies (Johnson\&Johnson) has developed a vaccine based on Ad26 vector encoding a full-length SARS-CoV-2 spike protein. A precise analysis reveals that the Ad26.COV2. S vaccine has an acceptable safety profile and its advantage with respect to the other vaccines is that this vaccine is immunogenic after one dose, with a local systemic reaction the day of immunization, or the following day, which resolves within $24 \mathrm{~h}$ [72]. In China, an inactivated variant of the SARS-CoV-2 virion produced in the Vero cells line is being used as a vaccine. The inactivation can be carried out using beta propiolactone and aluminiun hydroxide as an adjuvant. Alternatively, selfreplicating RNA (saRNA) vaccines are based on a donkey Venezuelan equine virus strain (VEEV), in which the self-amplification coding region is conserved while the structural coding region is replaced with prefusion-Spike protein of SARS-CoV-2. In this case, the saRNA can be wrapped in various forms of nanoparticles [73]. There are also DNA-based vaccines under investigation based on a consensus SARS-CoV-2 spike protein sequence and, in addition, to improve immunogenicity, an N-terminal IgE leader is added. In this way, the interaction between the virus and the ACE2 receptor is blocked [74]. A summary of principal vaccines against SARS-CoV-2 is reported in Table 4. 
Table 4. List of principal vaccines against SARS-CoV-2. In the table are indicated the type of vaccine such as messenger RNA (mRNA), self-replicating RNA (saRNA) , Inactivate Virus, Non-Replicating Viral Vector, Viral Vector and DNA. Each type of vaccine is associated with its specific name and the name of the company.

\begin{tabular}{|c|c|c|c|c|}
\hline & Name & Group & Clinical Status & Reference \\
\hline \multirow{3}{*}{ mRNA } & $\begin{array}{l}\text { 1) BNT162b2 and } \\
\text { BNT162b1; }\end{array}$ & $\begin{array}{l}\text { 1) BioNTech/Fosun } \\
\text { Pharma/Pfizer; }\end{array}$ & 1) Recruiting; & (1) NCT04368728 \\
\hline & 2) $\mathrm{CVnCoV}$ & 2) Curevac; & 2) Recruiting; & (2) NCT04652102 \\
\hline & 3) mRNA-1273. & 3) Moderna/NIAID. & 3) Recruiting; & (3) NCT04283461 \\
\hline \multirow[b]{2}{*}{ saRNA } & 1) ARCT-021; & 1) Arcturus/Duke-NUS; & 1) Recruiting; & (1) NCT04480957 \\
\hline & 2) LNP-nCoVsaRNA; & $\begin{array}{l}\text { 2) Imperial College } \\
\text { London; }\end{array}$ & 2) Phase I & $\begin{array}{c}\text { (2) https: / / doi.org/10.1186/ } \\
\text { ISRCTN17072692; }\end{array}$ \\
\hline \multirow{7}{*}{ Inactivate Virus } & 1) BBV152A/B; & $\begin{array}{l}\text { 1) Bharat Biotech; } \\
\text { 2) Research Institute for }\end{array}$ & 1) Active; & (1) NCT04471519 \\
\hline & 2) QazCovid-in ${ }^{\circledR}$; & $\begin{array}{l}\text { Biological safety } \\
\text { Problems, Republic } \\
\text { of Kazahstan; }\end{array}$ & 2) Active; & (2) NCT04691908 \\
\hline & $\begin{array}{l}\text { 3) Coron- } \\
\text { aVac/PiCoVacc; }\end{array}$ & $\begin{array}{l}\text { 3) Wuhan Institute } \\
\text { of Biological Products/ } \\
\text { Sinopharm }\end{array}$ & 3) Active; & (3) NCT04456595 \\
\hline & $\begin{array}{l}\text { 4) Inactivated } \\
\text { COVID-19 vaccine; }\end{array}$ & $\begin{array}{l}\text { 4) Wuhan Institute } \\
\text { of Biological } \\
\text { Products/Sinopharm }\end{array}$ & 4) Phase III; & (4) ChiCTR2000034780; \\
\hline & 5) BBIBP-CorV; & $\begin{array}{l}\text { 5) Bejing Institute } \\
\text { of Biological } \\
\text { Products/Sinopharm }\end{array}$ & $\begin{array}{l}\text { 5) Enrolling by } \\
\text { invitation; }\end{array}$ & (5) NCT04470609 \\
\hline & $\begin{array}{l}\text { 6) Inactivated } \\
\text { SARS-CoV-2 vaccine; }\end{array}$ & $\begin{array}{l}\text { 6) Institute of Medical } \\
\text { Biology, Chinese } \\
\text { Academy of } \\
\text { Medical Sciences }\end{array}$ & 6) Recruiting; & (6) NCT04795414 \\
\hline & 7) CoV-2 Vaccine. & $\begin{array}{l}\text { 7) Beijing Institute of } \\
\text { Biological Products Co } \\
\text { Ltd. China National } \\
\text { Biotec Group Company } \\
\text { Limited Fundación } \\
\text { Huésped }\end{array}$ & 7) Active. & (7) NCT04560881. \\
\hline $\begin{array}{l}\text { Non-Replicating } \\
\text { Viral Vector }\end{array}$ & $\begin{array}{c}\text { AZD1222 (ChAdOx1 } \\
\text { nCoV-19) }\end{array}$ & $\begin{array}{c}\text { University of } \\
\text { Oxford/AstraZeneca }\end{array}$ & Active & NCT04516746 \\
\hline \multirow{3}{*}{ Viral Vector } & 1) Ad26.COV2.S; & $\begin{array}{c}\text { 1) Janssen } \\
\text { Pharmaceutical } \\
\text { Companies } \\
\text { (Johnson\&Johnson) ; }\end{array}$ & 1) Active; & (1) NCT04505722 \\
\hline & $\begin{array}{l}\text { 2) Cansino Biological } \\
\text { Inc./ Bejing Institute of } \\
\text { Biotechnology; }\end{array}$ & 2) Ad5-nCoV; & 2) Active; & (2) NCT04552366 \\
\hline & $\begin{array}{l}\text { 3) Gamaleya Research } \\
\text { Institute. }\end{array}$ & 3) Gam-COVID-Vac. & 3) Active. & (3) NCT04564716. \\
\hline \multirow{3}{*}{ DNA } & $\begin{array}{l}\text { 1) AG0301-COVID19 } \\
\text { and AG0302-COVID19; }\end{array}$ & $\begin{array}{c}\text { 1) Osaka Univer- } \\
\text { sity/AnGes/Takara } \\
\text { Bio; }\end{array}$ & 1) Active; & (1) NCT04463472 \\
\hline & 2) INO-4800; & $\begin{array}{l}\text { 2) Inovio Pharmaceuti- } \\
\text { cals/International } \\
\text { Vaccine Institute; }\end{array}$ & 2) Active; & (2) NCT04642638 \\
\hline & 3) GX-19. & 3) Genexine Consortium. & 3) Recruiting. & (3) NCT04715997. \\
\hline
\end{tabular}

The abbreviation NIAD is used for National Institute of Allergy and Infectious Diseases. In the column clinical status is reported the current advancement of the clinical trial or if they are already been distributed to the population (Active). The references indicate the number of identifications on ClinicalTrials.gov that are identified with NCT followed by a number. In the case of Chinese registry are indicated with Chinese Clinical Trial Register (ChiCTR). 


\section{Conclusions and Future Directions}

The new pandemic caused by SARS-CoV-2 has made us more aware that coronaviruses are a threat that the scientific community must address. Indeed, the presence of a vast number of coronaviruses identified in bats, combined with their ability to accumulate mutations and rapidly change, makes future pandemics very likely. Many studies have confirmed that, as with previous SARS, SARS-CoV-2 uses ACE2 as a receptor for cell entry [1] although, as discussed above, increasing evidence is demonstrating that other receptors may be used by this new virus to enter the cells, which could explain its ability to infect multiple organs. Moreover, its increasing affinity to bind, due to a mutation in the Spike protein, has allowed it to rapidly spread in the population, causing severe pneumonia [75] and many deaths, especially among people suffering from hypertension, cardiovascular diseases $[33,76]$, and diabetes. A potential reason for the high susceptibility of these subjects to develop severe conditions is the important role the ACE2 plays in different physiological pathways, such as the RAAS and KKS, among others. Indeed, the decreased level of membrane ACE2 due to SARS-CoV-2 dependent internalization can cause an increase in the level of both AngII and DABK and LDABK. AngII has been demonstrated to over-activate its receptor AT1R, causing proinflammatory cytokines production, vasoconstriction, caspase activation, and oxidative stress. In the same fashion, DABK and LDABK can exacerbate the inflammation by promoting proinflammatory cytokine release and angioedema through their receptor BRB1. Therefore, therapies that would target one pathway but not the other will not be as effective in decreasing the inflammation. The important role that ACE2 plays in different physiological pathways can also explain why therapies used to date have had a moderate success that is mostly dependent on medical history and the severity of the disease at the beginning of the treatment. There is no doubt that only through reaching the herd immunity can the fight against COVID19 be won. In fact, although with many difficulties, the vaccination campaign started in all countries around the world should decrease the number of infected people requiring hospitalization.

Some concerns have been raised regarding the efficacy of the currently available vaccines against the newly identified SARS-CoV-2 variants [11]. Although, as we have discussed above, many mutations would have occur on the spike protein to allow it to completely escape the immune response, is also true that the rate of SARS-CoV-2 mutations appears to be quite high, challenging the future efficacy of the available vaccine. Therefore, it is important to clearly understand the role that ACE2 and the other receptors used by SARS-CoV-2 play in maintaining organismal physiology. This will help us to identify the most effective therapeutic approaches based on the individual patient's medical history.

Author Contributions: Conceptualization, F.S., M.V., A.D., E.N., F.P., M.G., C.I., F.S.C., A.C., V.A., F.A., L.P., G.C., A.B.; writing—original draft preparation, F.S., M.V., A.D., E.N., F.P., M.G., C.I., F.S.C., A.C., V.A., F.A., L.P., G.C., A.B.; writing-review and editing, F.S., M.V., A.D., E.N., F.P., M.G., C.I., F.S.C., A.C., V.A., F.A., L.P., G.C., A.B. All authors have read and agreed to the published version of the manuscript.

Funding: This research received no external funding.

Institutional Review Board Statement: Not applicable.

Informed Consent Statement: Not applicable.

Data Availability Statement: Not applicable.

Conflicts of Interest: The authors declare no conflict of interest.

\section{References}

1. Scialo, F.; Daniele, A.; Amato, F.; Pastore, L.; Matera, M.G.; Cazzola, M.; Castaldo, G.; Bianco, A. ACE2: The Major Cell Entry Receptor for SARS-CoV-2. Lung 2020, 198, 867-877. [CrossRef]

2. Talotta, R.; Robertson, E. Autoimmunity as the Comet Tail of COVID-19 Pandemic. World J. Clin. Cases 2020, 8, 3621-3644. [CrossRef] 
3. Matera, M.G.; Rogliani, P.; Bianco, A.; Cazzola, M. Pharmacological Management of Adult Patients with Acute Respiratory Distress Syndrome. Expert Opin. Pharmacother. 2020, 21, 2169-2183. [CrossRef]

4. Van De Veerdonk, F.L.; Netea, M.G.; Van Deuren, M.; Van Der Meer, J.W.; De Mast, Q.; Brüggemann, R.J.; Van Der Hoeven, H. Kallikrein-kinin Blockade in Patients with COVID-19 to Prevent Acute Respiratory Distress Syndrome. eLife 2020, 9, 1-9. [CrossRef] [PubMed]

5. Iadevaia, C.; Perrotta, F.; Mazzeo, G.; Cerqua, F.S.; Mazzarella, G.; Guarino, S.; Parrella, R.; Bianco, A. Incidental Diagnosis of Lung Adenocarcinoma Following Coronavirus OC 43 Severe Pneumonia. Monaldi Arch. Chest Dis. 2020, 90, 425-427. [CrossRef] [PubMed]

6. Cui, J.; Li, F.; Shi, Z.-L. Origin and Evolution of Pathogenic Coronaviruses. Nat. Rev. Microbiol. 2019, 17, 181-192. [CrossRef]

7. Zhou, P.; Yang, X.-L.; Wang, X.-G.; Hu, B.; Zhang, L.; Zhang, W.; Si, H.-R.; Zhu, Y.; Li, B.; Huang, C.-L.; et al. A Pneumonia Outbreak Associated with a New Coronavirus of Probable Bat Origin. Nature 2020, 579, 270-273. [CrossRef] [PubMed]

8. Andersen, K.G.; Rambaut, A.; Lipkin, W.I.; Holmes, E.C.; Garry, R.F. The Proximal Origin of SARS-CoV-2. Nat. Med. 2020, 26, 450-452. [CrossRef]

9. Pachetti, M.; Marini, B.; Benedetti, F.; Giudici, F.; Mauro, E.; Storici, P.; Masciovecchio, C.; Angeletti, S.; Ciccozzi, M.; Gallo, R.C.; et al. Emerging SARS-CoV-2 Mutation Hot Spots Include a Novel RNA-dependent-RNA Polymerase Variant. J. Transl. Med. 2020, 18, 1-9. [CrossRef]

10. Wu, F.; Zhao, S.; Yu, B.; Chen, Y.-M.; Wang, W.; Song, Z.-G.; Hu, Y.; Tao, Z.-W.; Tian, J.-H.; Pei, Y.-Y.; et al. A New Coronavirus Associated with Human Respiratory Disease in China. Nature 2020, 579, 265-269. [CrossRef]

11. Fontanet, A.; Autran, B.; Lina, B.; Kieny, M.P.; Karim, S.S.A.; Sridhar, D. SARS-CoV-2 Variants and Ending the COVID-19 Pandemic. Lancet 2021, 397, 952-954. [CrossRef]

12. Wibmer, C.K.; Ayres, F.; Hermanus, T.; Madzivhandila, M.; Kgagudi, P.; Oosthuysen, B.; Lambson, B.E.; de Oliveira, T.; Vermeulen, M.; van der Berg, K.; et al. SARS-CoV-2 501Y.V2 Escapes Neutralization by South African COVID-19 Donor Plasma. Nat. Med. 2021, 27, 622-625. [CrossRef]

13. Hoffmann, M.; Arora, P.; Groß, R.; Seidel, A.; Hörnich, B.F.; Hahn, A.S.; Krüger, N.; Graichen, L.; Hofmann-Winkler, H.; Kempf, A.; et al. SARS-CoV-2 Variants B.1.351 and P.1 Escape from Neutralizing Antibodies. Cell 2021, 1-10. [CrossRef]

14. Conceicao, C.; Thakur, N.; Human, S.; Kelly, J.T.; Logan, L.; Bialy, D.; Bhat, S.; Stevenson-Leggett, P.; Zagrajek, A.K.; Hollinghurst, P.; et al. The SARS-CoV-2 Spike Protein Has a Broad Tropism for Mammalian ACE2 Proteins. PLoS Biol. 2020, 18, e3001016. [CrossRef]

15. Perrotta, F.; Gabriella, M.; Cazzola, M.; Bianco, A. Severe respiratory SARS-CoV2 infection: Does ACE2 receptor matter? Respir. Med. 2020, 168, 105996. [CrossRef]

16. Hoffmann, M.; Kleine-Weber, H.; Schroeder, S.; Krüger, N.; Herrler, T.; Erichsen, S.; Schiergens, T.S.; Herrler, G.; Wu, N.-H.; Nitsche, A.; et al. SARS-CoV-2 Cell Entry Depends on ACE2 and TMPRSS2 and Is Blocked by a Clinically Proven Protease Inhibitor. Cell 2020, 181, 271-280. [CrossRef] [PubMed]

17. Ou, X.; Liu, Y.; Lei, X.; Li, P.; Mi, D.; Ren, L.; Guo, L.; Guo, R.; Chen, T.; Hu, J.; et al. Characterization of Spike Glycoprotein of SARS-CoV-2 on Virus Entry and Its Immune Cross-reactivity with SARS-CoV. Nat. Commun. 2020, 11, 1-12. [CrossRef] [PubMed]

18. Wang, K.; Chen, W.; Zhang, Z.; Deng, Y.; Lian, J.-Q.; Du, P.; Wei, D.; Zhang, Y.; Sun, X.-X.; Gong, L.; et al. CD147-spike Protein is a Novel Route for SARS-CoV-2 Infection to Host Cells. Signal Transduct. Target. Ther. 2020, 5, 1-10. [CrossRef] [PubMed]

19. Qiao, J.; Li, W.; Bao, J.; Peng, Q.; Wen, D.; Wang, J.; Sun, B. The Expression of SARS-CoV-2 Receptor ACE2 and CD147, and Protease TMPRSS2 in Human and Mouse Brain Cells and Mouse Brain Tissues. Biochem. Biophys. Res. Commun. 2020, 533, 867-871. [CrossRef] [PubMed]

20. Cantuti-Castelvetri, L.; Ojha, R.; Pedro, L.D.; Djannatian, M.; Franz, J.; Kuivanen, S.; Van Der Meer, F.; Kallio, K.; Kaya, T.; Anastasina, M.; et al. Neuropilin-1 Facilitates SARS-CoV-2 Cell Entry and Infectivity. Science 2020, eabd2985. [CrossRef]

21. Guan, W.J.; Ni, Z.Y.; Hu, Y.; Liang, W.H.; Ou, C.Q.; He, J.X.; Liu, L.; Shan, H.; Lei, C.L.; Hui, D.S.C.; et al. Clinical Characteristics of Coronavirus Disease 2019 in China. N. Engl. J. Med. 2020, 382, 1708-1720. [CrossRef]

22. Yin, X.; Riva, L.; Pu, Y.; Martin-Sancho, L.; Kanamune, J.; Yamamoto, Y.; Sakai, K.; Gotoh, S.; Miorin, L.; De Jesus, P.D.; et al MDA5 Governs the Innate Immune Response to SARS-CoV-2 in Lung Epithelial Cells. Cell Rep. 2021, 34, 108628. [CrossRef] [PubMed]

23. Rebendenne, A.; Valadão, A.L.C.; Tauziet, M.; Maarifi, G.; Bonaventure, B.; McKellar, J.; Planès, R.; Nisole, S.; Arnaud-Arnould, M.; Moncorgé, O.; et al. SARS-CoV-2 Triggers an MDA-5-Dependent Interferon Response Which Is Unable to Control Replication in Lung Epithelial Cells. J. Virol. 2021, 95, 1-17. [CrossRef] [PubMed]

24. Li, Y.; Renner, D.M.; Comar, C.E.; Whelan, J.N.; Reyes, H.M.; Cardenas-Diaz, F.L.; Truitt, R.; Tan, L.H.; Dong, B.; Alysandratos, K.D.; et al. SARS-CoV-2 Induces Double-stranded RNA-mediated Innate Immune Responses in Respiratory Epithelial-derived Cells and Cardiomyocytes. Proc. Natl. Acad. Sci. USA 2021, 118, 1-11. [CrossRef] [PubMed]

25. Hu, Y.; Li, W.; Gao, T.; Cui, Y.; Jin, Y.; Li, P.; Ma, Q.; Liu, X.; Cao, C. The Severe Acute Respiratory Syndrome Coronavirus Nucleocapsid Inhibits Type I Interferon Production by Interfering with TRIM25-Mediated RIG-I Ubiquitination. J. Virol. 2017, 91, e02143-16. [CrossRef]

26. Liu, G.; Lee, J.-H.; Parker, Z.M.; Acharya, D.; Chiang, J.J.; van Gent, M.; Riedl, W.; Davis-Gardner, M.E.; Wies, E.; Chiang, C.; et al. ISG15-dependent Activation of the Sensor MDA5 is Antagonized by the SARS-CoV-2 Papain-like Protease to Evade Host Innate Immunity. Nat. Microbiol. 2021, 6, 1-12. [CrossRef] 
27. Wang, W.; Zhou, Z.; Xiao, X.; Tian, Z.; Dong, X.; Wang, C.; Li, L.; Ren, L.; Lei, X.; Xiang, Z.; et al. SARS-CoV-2 nsp12 Attenuates Type I Interferon Production by Inhibiting IRF3 Nuclear Translocation. Cell. Mol. Immunol. 2021, 18, 1-9. [CrossRef]

28. Jose, R.J.; Manuel, A. COVID-19 Cytokine Storm: The Interplay between Inflammation and Coagulation. Lancet Respir. Med. 2020, 8, e46-e47. [CrossRef]

29. Laing, A.G.; Lorenc, A.; Del Barrio, I.D.M.; Das, A.; Fish, M.; Monin, L.; Davis, R.; Zlatareva, I.; Wu, Y.; Hayday, A.C.; et al. Author Correction: A Dynamic COVID-19 Immune Signature Includes Associations with Poor Prognosis. Nat. Med. 2020, 26. [CrossRef]

30. Rysz, S.; Al-Saadi, J.; Sjöström, A.; Farm, M.; Jalde, F.C.; Plattén, M.; Eriksson, H.; Klein, M.; Vargas-Paris, R.; Nyrén, S.; et al. COVID-19 Pathophysiology May be Driven by an Imbalance in the Renin-angiotensin-aldosterone System. Nat. Commun. 2021, 12, 1-12. [CrossRef] [PubMed]

31. Lipcsey, M.; Persson, B.; Eriksson, O.; Blom, A.M.; Fromell, K.; Hultström, M.; Huber-Lang, M.; Ekdahl, K.N.; Frithiof, R.; Nilsson, B. The Outcome of Critically Ill COVID-19 Patients Is Linked to Thromboinflammation Dominated by the Kallikrein/Kinin System. Front. Immunol. 2021, 12, 627579. [CrossRef]

32. Mansour, E.; Palma, A.; Ulaf, R.; Ribeiro, L.; Bernardes, A.; Nunes, T.; Agrela, M.; Bombassaro, B.; Monfort-Pires, M.; Camargo, R.; et al. Safety and Outcomes Associated with the Pharmacological Inhibition of the Kinin-Kallikrein System in Severe COVID-19. Viruses 2021, 13, 309. [CrossRef]

33. Carfora, V.; Spiniello, G.; Ricciolino, R.; Di Mauro, M.; Migliaccio, M.G.; Mottola, F.F.; Verde, N.; Coppola, N. Anticoagulant Treatment in COVID-19: A Narrative Review. J. Thromb. Thrombolysis 2021, 51, 642-648. [CrossRef]

34. Boccia, M.; Aronne, L.; Celia, B.; Mazzeo, G.; Ceparano, M.; D’Agnano, V.; Parrella, R.; Valente, T.; Bianco, A.; Perrotta, F. COVID-19 and Coagulative Axis: Review of Emerging Aspects in a Novel Disease. Monaldi Arch. Chest Dis. 2020, 90, 271-276. [CrossRef]

35. Perrotta, F.; Corbi, G.; Mazzeo, G.; Boccia, M.; Aronne, L.; D’Agnano, V.; Komici, K.; Mazzarella, G.; Parrella, R.; Bianco, A. COVID-19 and the Elderly: Insights into Pathogenesis and Clinical Decision-making. Aging Clin. Exp. Res. 2020, 32, 1599-1608. [CrossRef] [PubMed]

36. Sanyaolu, A.; Okorie, C.; Marinkovic, A.; Patidar, R.; Younis, K.; Desai, P.; Hosein, Z.; Padda, I.; Mangat, J.; Altaf, M. Comorbidity and Its Impact on Patients with COVID-19. SN Compr. Clin. Med. 2020, 2, 1069-1076. [CrossRef]

37. Kompaniyets, L.; Goodman, A.B.; Belay, B.; Freedman, D.S.; Sucosky, M.S.; Lange, S.J.; Gundlapalli, A.V.; Boehmer, T.K.; Blanck, H.M. Body Mass Index and Risk for COVID-19-Related Hospitalization, Intensive Care Unit Admission, Invasive Mechanical Ventilation, and Death-United States, March-December 2020. MMWR. Morb. Mortal. Wkly. Rep. 2021, 70, 355-361. [CrossRef] [PubMed]

38. Zhonghua, L.; Xing, B.; Xue, Z.Z. Epidemiology Working Group for NCIP Epidemic Response, Chinese Center for Disease Control and Prevention. The Epidemiological Characteristics of an Outbreak of 2019 Novel Coronavirus Diseases (COVID-19) in China. Nat. Libr. Med. 2020, 41. [CrossRef]

39. Xie, J.; Tong, Z.; Guan, X.; Du, B.; Qiu, H. Clinical Characteristics of Patients Who Died of Coronavirus Disease 2019 in China. JAMA Netw. Open 2020, 3, e205619. [CrossRef] [PubMed]

40. Huang, C.; Wang, Y.; Li, X.; Ren, L.; Zhao, J.; Hu, Y.; Xiao, Y.; Guo, L.; Liu, M.; Cao, B.; et al. Clinical Features of Patients Infected with 2019 Novel Coronavirus in Wuhan, China. Lancet 2020, 395, 497-506. [CrossRef]

41. Zhang, J.J.; Dong, X.; Cao, Y.Y.; Yuan, Y.D.; Yang, Y.B.; Yan, Y.Q.; Akdis, C.A.; Gao, Y.D. Clinical Characteristics of 140 Patients Infected with SARS-CoV-2 in Wuhan, China. Allergy 2020, 75, 1730-1741. [CrossRef] [PubMed]

42. Li, Q.; Guan, X.; Wu, P.; Wang, X.; Zhou, L.; Tong, Y.; Ren, R.; Leung, K.S.M.; Lau, E.H.Y.; Wong, J.Y.; et al. Early Transmission Dynamics in Wuhan, China, of Novel Coronavirus-Infected Pneumonia. N. Engl. J. Med. 2020, 382, 1199-1207. [CrossRef] [PubMed]

43. Wang, D.; Hu, B.; Hu, C.; Zhu, F.; Liu, X.; Zhang, J.; Wang, B.; Xiang, H.; Cheng, Z.; Xiong, Y.; et al. Clinical Characteristics of 138 Hospitalized Patients With 2019 Novel Coronavirus-Infected Pneumonia in Wuhan, China. Jama 2020, 323, 1061-1069. [CrossRef] [PubMed]

44. Chen, N.; Zhou, M.; Dong, X.; Qu, J.; Gong, F.; Han, Y.; Qiu, Y.; Wang, J.; Liu, Y.; Wei, Y.; et al. Epidemiological and Clinical Characteristics of 99 Cases of 2019 Novel Coronavirus Pneumonia in Wuhan, China: A Descriptive Study. Lancet 2020, 395, 507-513. [CrossRef]

45. Shi, H.; Han, X.; Jiang, N.; Cao, Y.; Alwalid, O.; Gu, J.; Fan, Y.; Zheng, C. Radiological Findings from 81 Patients with COVID-19 Pneumonia in Wuhan, China: A Descriptive Study. Lancet Infect. Dis. 2020, 20, 425-434. [CrossRef]

46. Liang, W.H.; Guan, W.J.; Li, C.C.; Li, Y.M.; Liang, H.R.; Zhao, Y.; He, J.X. Clinical characteristics and outcomes of hospitalised patients with COVID-19 treated in Hubei (epicentre) and outside Hubei (non-epicentre) : A nationwide analysis of China. Eur. Respir. J. 2020, 55. [CrossRef]

47. Dong, Y.; Mo, X.; Hu, Y.; Qi, X.; Jiang, F.; Jiang, Z.; Tong, S. Epidemiology of COVID-19 Among Children in China. Pediatrics 2020, 145, e20200702. [CrossRef] [PubMed]

48. Davies, N.G.; Klepac, P.; Liu, Y.; Prem, K.; Jit, M.; Eggo, R.M. Age-dependent Effects in the Transmission and Control of COVID-19 Epidemics. Nat. Med. 2020, 26, 1205-1211. [CrossRef]

49. Giannattasio, A.; Brunese, L.; Ripabelli, G.; Mazzarella, G.; Bianco, A. Coinfections with Influenza Virus and Atypical Bacteria: Implications for Severe Outcomes? Clin. Respir. J. 2016, 12, 366-367. [CrossRef] 
50. Heidary, F.; Gharebaghi, R. Ivermectin: A Systematic Review from Antiviral Effects to COVID-19 Complementary Regimen. J. Antibiot. 2020, 73, 593-602. [CrossRef]

51. Gao, J.; Tian, Z.; Yang, X. Breakthrough: Chloroquine Phosphate Has Shown Apparent Efficacy in Treatment of COVID-19 Associated Pneumonia in Clinical Studies. Biosci. Trends 2020, 14, 72-73. [CrossRef]

52. Gautret, P.; Lagier, J.; Parola, P.; Hoang, V.T. Hydroxychloroquine and azithromycin as a treatment of COVID-19: Results of an open-label non-randomized clinical trial. Int. J. Antimicrob. Agents 2020, 56. [CrossRef]

53. Schilling, W.H.; White, N.J. Does Hydroxychloroquine Still Have Any Role in the COVID-19 Pandemic? Expert Opin. Pharmacother. 2021, 00, 1-10. [CrossRef] [PubMed]

54. Sevilla-Castillo, F.; Roque-Reyes, O.J.; Romero-Lechuga, F.; Gómez-Núñez, M.F.; Castillo-López, M.; Medina-Santos, D.; Román, P.O.; Flores-Hernández, J.R.; Méndez-Coca, J.D.; Montaño-Olmos, D.; et al. Both Chloroquine and Lopinavir/Ritonavir Are Ineffective for COVID-19 Treatment and Combined Worsen the Pathology: A Single-Center Experience with Severely Ill Patients. BioMed Res. Int. 2021, 2021, 1-12. [CrossRef] [PubMed]

55. Capoluongo, E.D.; Amato, F.; Castaldo, G. The Friendly Use of Chloroquine in the COVID-19 Disease: A Warning for the G6PD-deficient Males and for the Unaware Carriers of Pathogenic Alterations of the G6PD Gene. Clin. Chem. Lab. Med. 2020, 58, 1162-1164. [CrossRef]

56. Mahase, E. Covid-19: Remdesivir is Helpful but Not a Wonder Drug, Say Researchers. BMJ 2020, 369, m1798. [CrossRef] [PubMed]

57. Beigel, J.H.; Tomashek, K.M.; Dodd, L.E.; Mehta, A.K.; Zingman, B.S.; Kalil, A.C.; Hohmann, E.; Chu, H.Y.; Luetkemeyer, A.; Kline, S.; et al. Remdesivir for the Treatment of Covid-19_Final Report. N. Engl. J. Med. 2020, 383, 1813-1826. [CrossRef]

58. Cai, Q.; Yang, M.; Liu, D.; Chen, J.; Shu, D.; Xia, J.; Liao, X.; Gu, Y.; Cai, Q.; Yang, Y.; et al. Experimental Treatment with Favipiravir for COVID-19: An Open-Label Control Study. Engineering 2020. [CrossRef]

59. Bloch, E.M.; Shoham, S.; Casadevall, A.; Sachais, B.S.; Shaz, B.; Winters, J.L.; Van Buskirk, C.; Grossman, B.J.; Joyner, M.; Henderson, J.P.; et al. Deployment of Convalescent Plasma for the Prevention and Treatment of COVID-19. J. Clin. Investig. 2020, 130, 2757-2765. [CrossRef]

60. Young, J.; Thone, M.N.; Jik, Y. COVID-19 vaccines: The status and perspectives in delivery points of view. Adv. Drug Deliv. Rev. 2021, 170, 1-25. [CrossRef]

61. Thanh Le, T.; Andreadakis, Z.; Kumar, A.; Gómez Román, R.; Tollefsen, S.; Saville, M.; Mayhew, S. The COVID-19 Vaccine Development Landscape. Nat. Rev. Drug Discov. 2020, 19, 305-306. [CrossRef]

62. Polack, F.P.; Thomas, S.J.; Kitchin, N.; Absalon, J.; Gurtman, A.; Lockhart, S.; Perez, J.L.; Marc, G.P.; Moreira, E.D.; Zerbini, C.; et al. Safety and Efficacy of the BNT162b2 mRNA Covid-19 Vaccine. N. Engl. J. Med. 2020, 383, 2603-2615. [CrossRef]

63. Schlake, T.; Thess, A.; Fotin-Mleczek, M.; Kallen, K.-J. Developing mRNA-vaccine Technologies. RNA Biol. 2012, 9, 1319-1330. [CrossRef]

64. Hassett, K.J.; Benenato, K.E.; Jacquinet, E.; Lee, A.; Woods, A.; Yuzhakov, O.; Himansu, S.; Deterling, J.; Geilich, B.M.; Ketova, T.; et al. Optimization of Lipid Nanoparticles for Intramuscular Administration of mRNA Vaccines. Mol. Ther. Nucleic Acids 2019, 15, 1-11. [CrossRef] [PubMed]

65. Karikó, K.; Muramatsu, H.; Ludwig, J.; Weissman, D. Generating the Optimal mRNA for Therapy: HPLC Purification Eliminates Immune Activation and Improves Translation of Nucleoside-modified, Protein-encoding mRNA. Nucleic Acids Res. 2011, 39 , e142. [CrossRef]

66. Jackson, L.A.; Anderson, E.J.; Rouphael, N.G.; Roberts, P.C.; Makhene, M.; Coler, R.N.; McCullough, M.P.; Chappell, J.D.; Denison, M.R.; Stevens, L.J.; et al. An mRNA Vaccine against SARS-CoV-2-Preliminary Report. N. Engl. J. Med. 2020, 383, $1920-1931$. [CrossRef]

67. Mulligan, M.J.; Lyke, K.E.; Kitchin, N.; Absalon, J.; Gurtman, A.; Lockhart, S.; Neuzil, K.; Raabe, V.; Bailey, R.; Swanson, K.A.; et al. Phase I/II Study of COVID-19 RNA Vaccine BNT162b1 in Adults. Nature 2020, 586, 589-593. [CrossRef] [PubMed]

68. Anderson, E.J.; Rouphael, N.G.; Widge, A.T.; Jackson, L.A.; Roberts, P.C.; Makhene, M.; Chappell, J.D.; Denison, M.R.; Stevens, L.J.; Pruijssers, A.J.; et al. Safety and Immunogenicity of SARS-CoV-2 mRNA-1273 Vaccine in Older Adults. N. Engl. J. Med. 2020. [CrossRef] [PubMed]

69. Tripodi, L.; Vitale, M.; Cerullo, V.; Pastore, L. Oncolytic Adenoviruses for Cancer Therapy. Int. J. Mol. Sci. 2021, 22, 2517. [CrossRef]

70. Lion, T. Adenovirus Infections in Immunocompetent and Immunocompromised Patients. Clin. Microbiol. Rev. 2014, 27, 441-462. [CrossRef] [PubMed]

71. Folegatti, P.M.; Ewer, K.J.; Aley, P.K.; Angus, B.; Becker, S.; Belij-Rammerstorfer, S.; Bellamy, D.; Bibi, S.; Bittaye, M.; Clutterbuck, E.A.; et al. Safety and Immunogenicity of the ChAdOx1 nCoV-19 Vaccine against SARS-CoV-2: A Preliminary Report of a Phase 1/2, Single-blind, Randomised Controlled Trial. Lancet 2020, 396, 467-478. [CrossRef]

72. Sadoff, J.; Le Gars, M.; Shukarev, G.; Heerwegh, D.; Truyers, C.; de Groot, A.M.; Stoop, J.; Tete, S.; Van Damme, W.; Leroux-Roels, I.; et al. Interim Results of a Phase 1-2a Trial of Ad26.COV2. S Covid-19 Vaccine. N. Engl. J. Med. 2021, 384, 1824-1835. [CrossRef]

73. McKay, P.F.; Hu, K.; Blakney, A.K.; Samnuan, K.; Brown, J.C.; Penn, R.; Zhou, J.; Bouton, C.R.; Rogers, P.; Polra, K.; et al. Self-amplifying RNA SARS-CoV-2 Lipid Nanoparticle Vaccine Candidate Induces High Neutralizing Antibody Titers in Mice. Nat. Commun. 2020, 11, 1-7. [CrossRef] 
74. Smith, T.R.F.; Patel, A.; Ramos, S.; Elwood, D.; Zhu, X.; Yan, J.; Gary, E.N.; Walker, S.N.; Schultheis, K.; Purwar, M.; et al. Immunogenicity of a DNA Vaccine Candidate for COVID-19. Nat. Commun. 2020, 11, 2601. [CrossRef] [PubMed]

75. Sagnelli, C.; Celia, B.; Monari, C.; Cirillo, S.; De Angelis, G.; Bianco, A.; Coppola, N. Management of SARS-CoV-2 Pneumonia. J. Med. Virol. 2021, 93, 1276-1287. [CrossRef] [PubMed]

76. Nigro, E.; Perrotta, F.; Polito, R.; D’Agnano, V.; Scialò, F.; Bianco, A.; Daniele, A. Metabolic Perturbations and Severe COVID-19 Disease: Implication of Molecular Pathways. Int. J. Endocrinol. 2020, 2020, 1-10. [CrossRef] [PubMed] 